تأثير تنش خشكى مرحله زايشى بر ويزَى هاى جوانهزنى بذر زنوتيٍهاى بومى و اصلاحشده برنج (Oryza sativa)

$$
\begin{aligned}
& \text { سيده ارحامه فلاح شمسى '، همتاله يِيردشتى ז×"، على اكبر عبادى"، مسعود اصفهانى"، محمود رائينى هـ }
\end{aligned}
$$

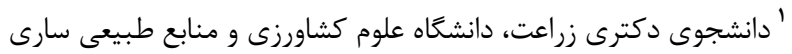

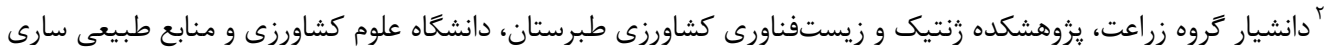

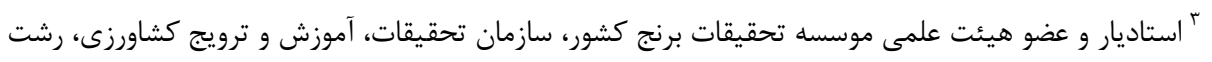

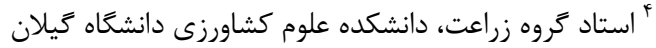

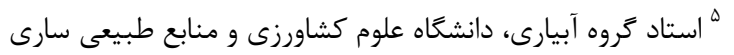

$$
\begin{aligned}
& \text { "بّست الكترونيك نويسنده مسئول: }
\end{aligned}
$$

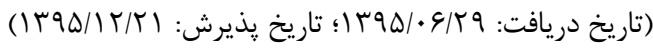

جكيده

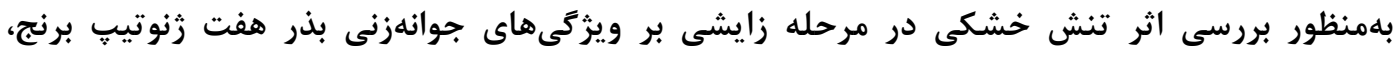

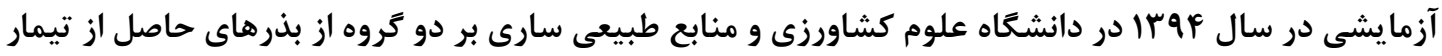

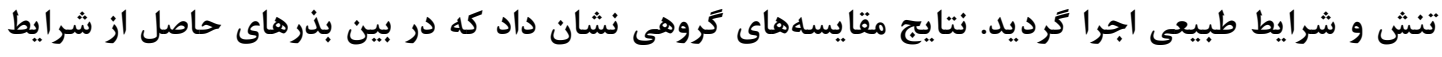

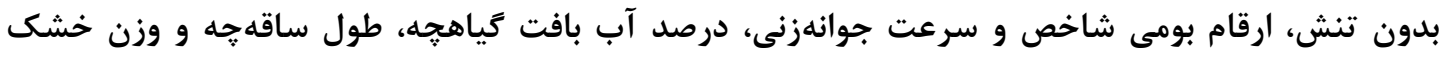

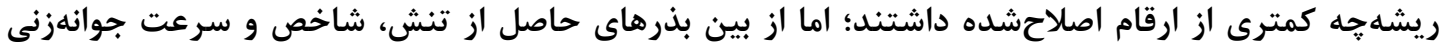

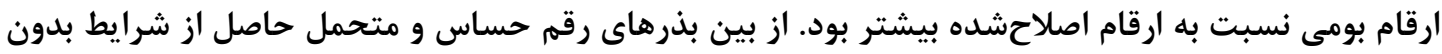

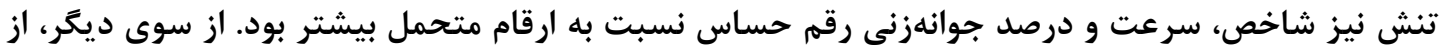

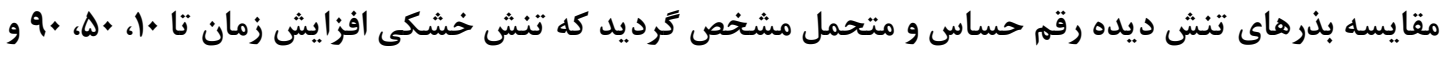

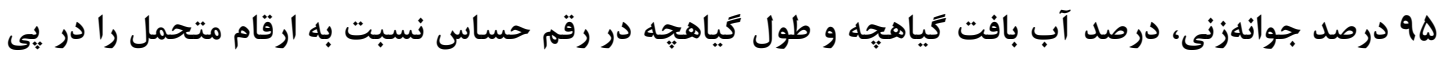

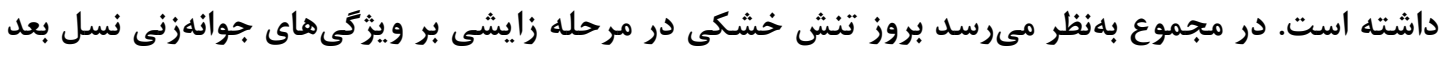

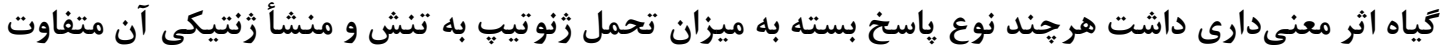

$$
\text { وازههاى كليدى: بذر تنش ديده، جرمين، شاخص بنيه، ضريب آلومتريك }
$$

جنبه هاى نوآورى:

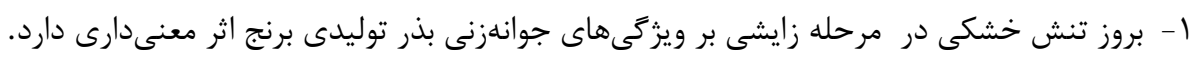

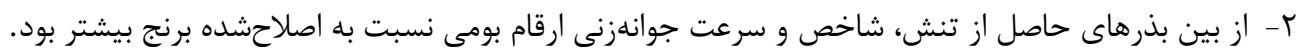

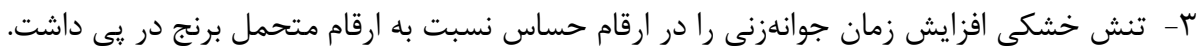

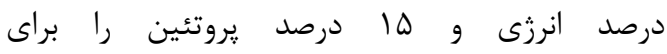
مقدمه مصرفكنندكان فراهم مى كند، از اينرو توجه به كميت

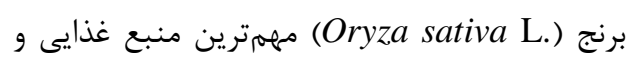
تأمينكننده كالرى در كشورهاى آسيايى است كه 


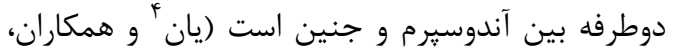

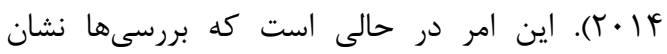

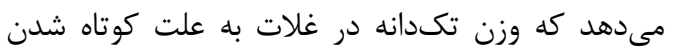

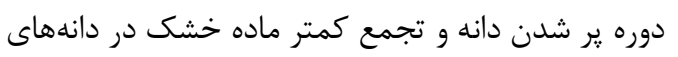

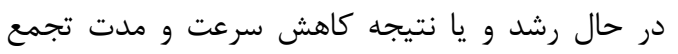

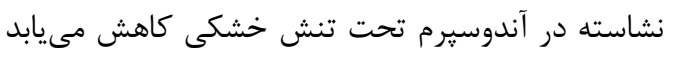

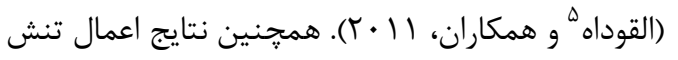

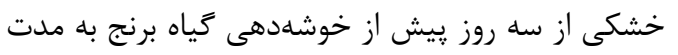

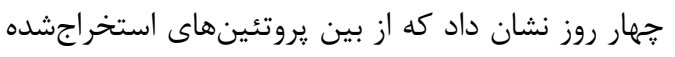

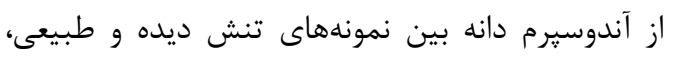

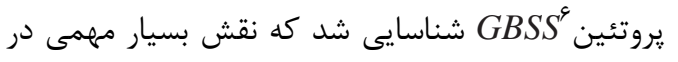

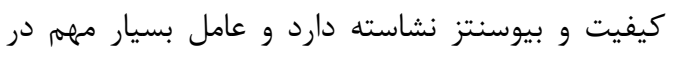
تعيين كيفيت دانه برنج است (مشتاق ل و همكاران،

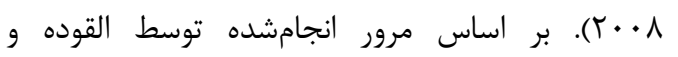

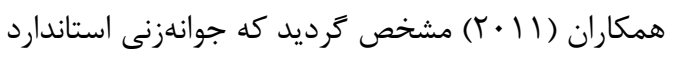

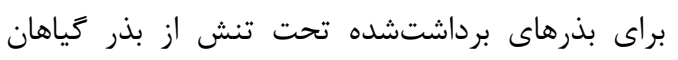

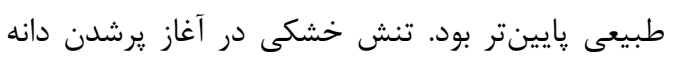

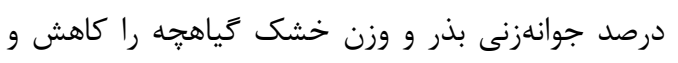

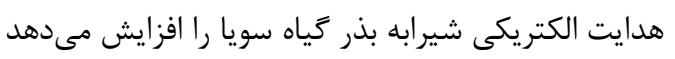

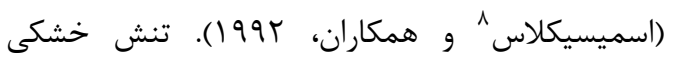

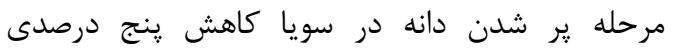

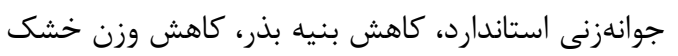

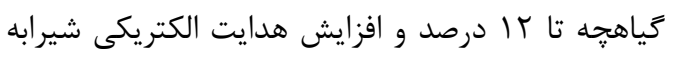

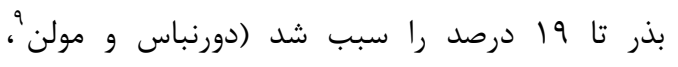

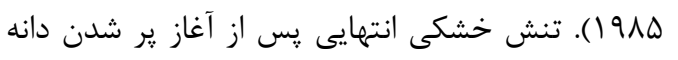

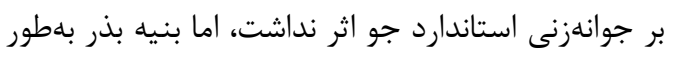

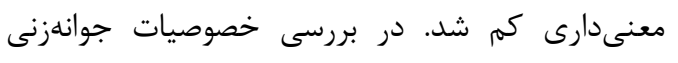

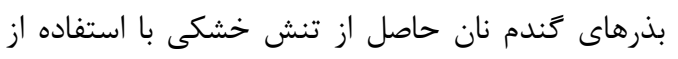

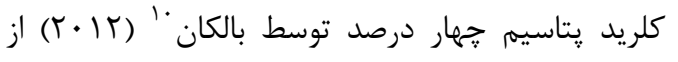

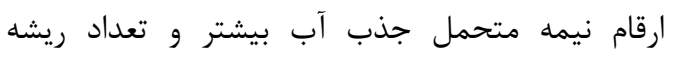

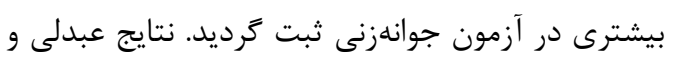

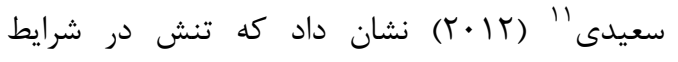

\footnotetext{
${ }^{4}$ Yan

${ }^{5}$ Alqudah

${ }^{6}$ Granule-Bound Starch Synthase

${ }^{7}$ Mushtaq

${ }^{8}$ Smiciklas

${ }^{9}$ Dornbos and Mullen

${ }^{10}$ Balkan

11 Abdoli and Saeidi
}

و كيفيت آن حائز اهميت است (زيبايى ' سا • ()). طبق كزارش وزارت جهاد كشاورزى، مازندران و كيلان به ترتيب با V و و T/T درصد از وسه هزار هكتار سطح زير كشت شلتوك در كشور، بيشترين سطح كشت برنج

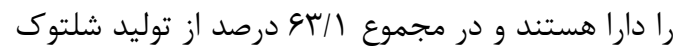
كشور متعلق به اين دو استان ساحلى است. اين امر در حالى است كه بر اساس ززارش مركز يايش و هشدار

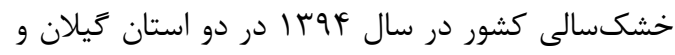
مازندران به ترتيب FV/q و FF/9 درصد از اراضى اين دو استان تحت تأثير خشكى خفيف، 19/T و و خشكى متوسط و l/1 و و 9/1 درصد تحت خشكى شديد قرار داشتهاند. همجنين اين مركز ززارش كرده است كه

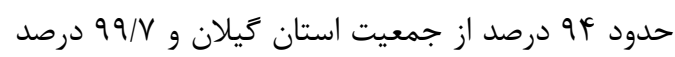
از جمعيت استان مازندران تحت تأثير خشكسالى بودند.

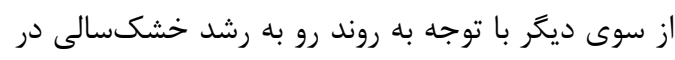

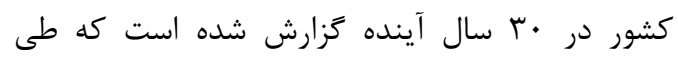

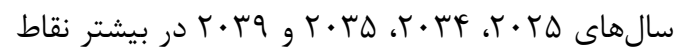
كشور از جمله مناطق شمال شرق و شمال غرب،

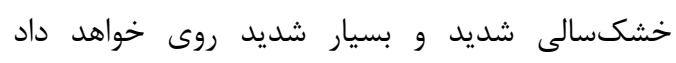

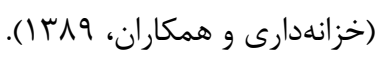
در بين عوامل مختلف مؤثر بر توليد محصولات

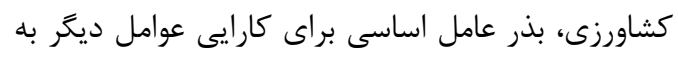

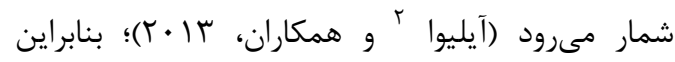
استفاده از بذرهاى با كيفيت بالا مىتواند بخشى از

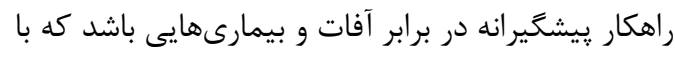
هزينه كم و همكام با حفاظت محيطى، افزايش عملكرد

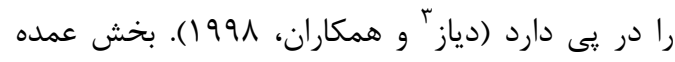
بافت بذر در غلات آندوسيرم نشاستهاى است كه نقش

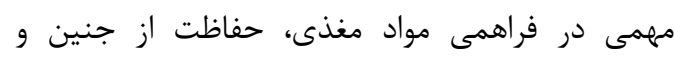

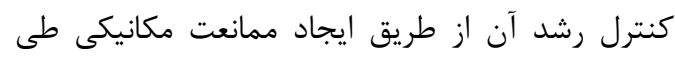
توسعه و جوانهزنى بذر بازى مى كند. جنين به آندوسيرم

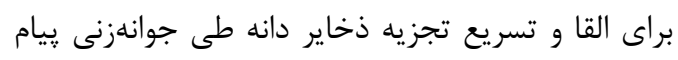
مىدهد، در مقابل آندوسيرم نيز قادر است كه بي تِامهاى محيطى را حس كرده و ييغامهايى براى تنظيم رشد دمايل جنين ارسال نمايد. در حقيقت جوانهنى رِاسخ نظاممند

\footnotetext{
${ }^{1}$ Zibaee

${ }^{2}$ Ilieva

${ }^{3}$ Diaz
} 
مزرعه) و شرايط تنش خشكى با قطع آبيارى از مرحله

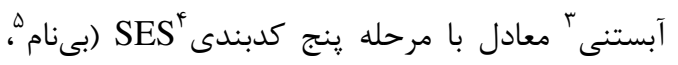

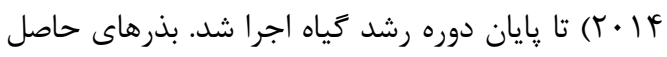

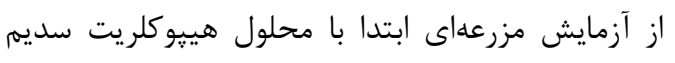

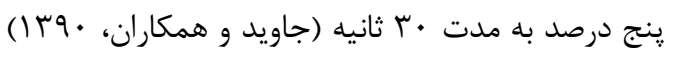

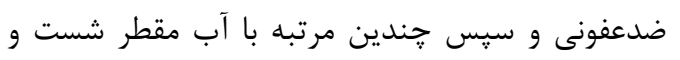
شو و هوا خشك شدند.

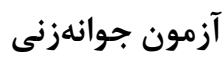

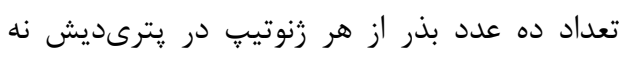

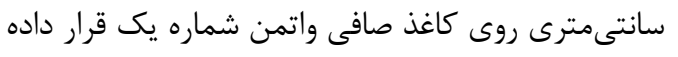

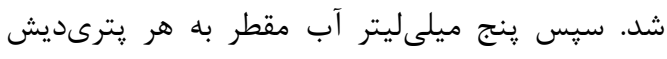

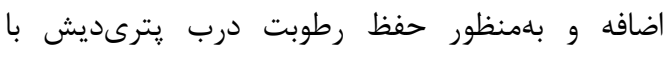

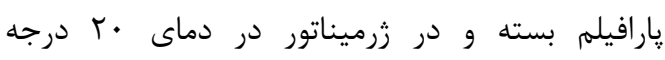

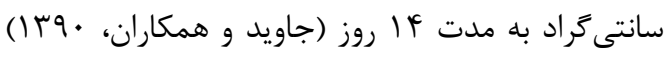

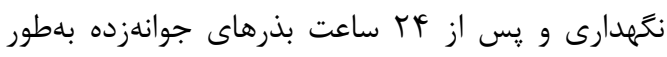
روزانه شمارش شدند.

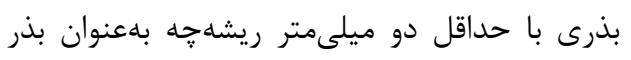

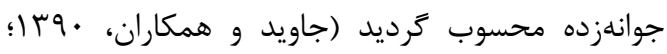

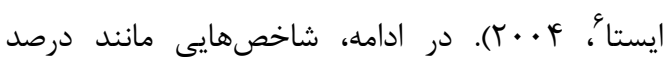

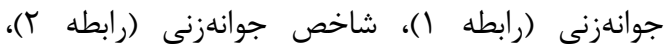
شاخص بنيه كياهجه (رابطه r) و انرزى جوانهزنى (رابطه |F) محاسبه شدند.

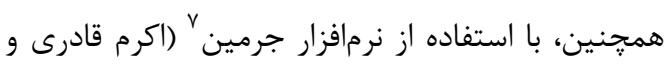

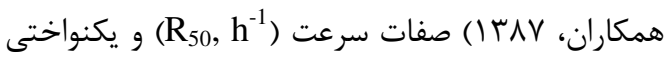

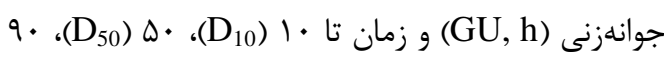

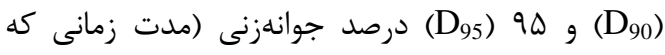

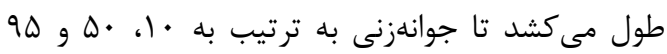

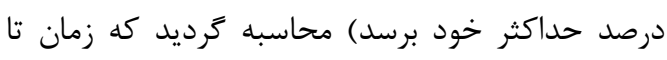

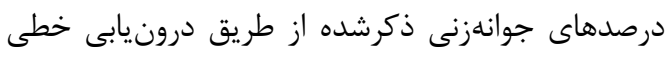

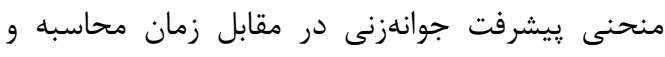

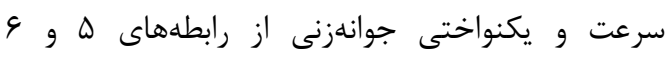
بهدست آمد.

\footnotetext{
${ }^{3}$ Booting

${ }^{4}$ Standard Evaluation System

${ }^{5}$ Anonymous

${ }^{6}$ ISTA

${ }^{7}$ Germine
}

مزرعهاى سبب كاهش در تمامى صفات جوانهزنى بذر كَندم بهجز نسبت ساقهجه به ريشه

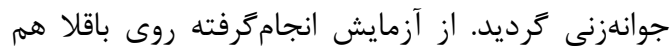

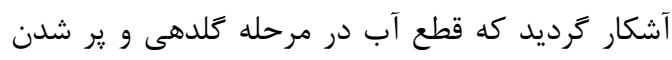

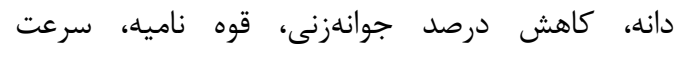
جوانهنى و وزن خشك گياهجه را به دنبه (قاسمى كَلعذانى' و و همكاران،

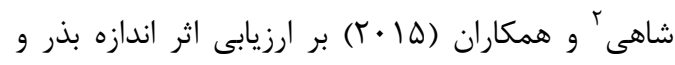
تنش آبى بر ويزگى هاى جوانهزنى گَندم مشاهده شد كه بذرهاى بزرى بيشترين درصد جوانهزنى را داشتند و و بانى كوجٌ شدن اندازه بذر ميزان جوانهزنى كاهش يافت.

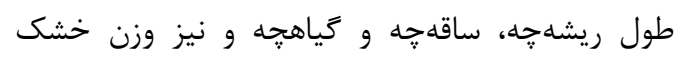

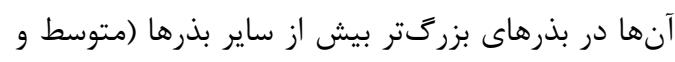

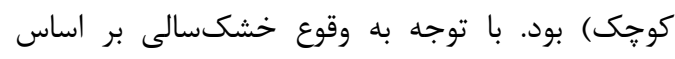

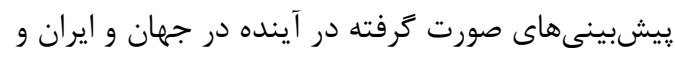

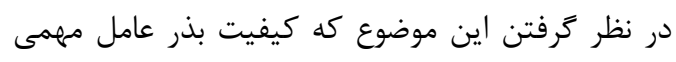
در توليد محصولات كشاورزى است و از سوى ديخر در ايران بخش زيادى از بذرهاى استفادهده براى كشت در هر فصل زراعى بذرهاى خودمصرفى توسط كشاورزان است، هدف از انجام يزوهش حاضر ارزيابى اثر تنش

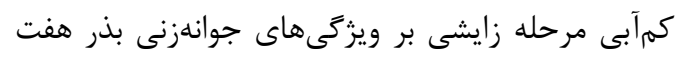

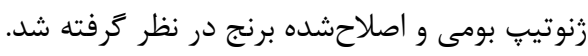

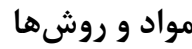

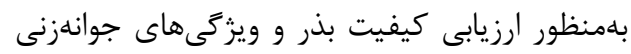
بذرهاى برنج حاصل از رشد تحت تنش خشكى، آزمون جوانهزنى روى هفت زنوتي» بومى و اصلاحشده برنج على كاظمى، اهلمى طارم، شيرودى، ندا، گيلانه، لاين

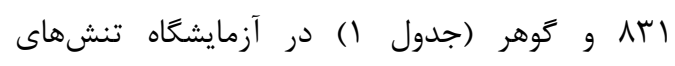

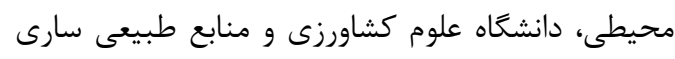

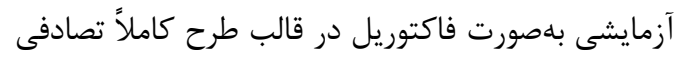

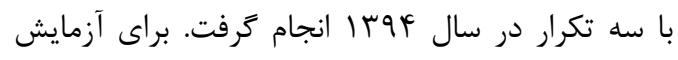
حاضر، از بذرهاى آزمايش مزرعهاى اجراشده در سال

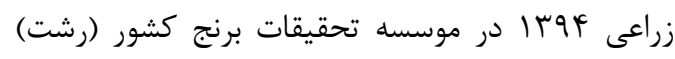
استفاده گرديد. آزمايش مزرعهاى در دو شرايط آبيارى سنتى (عمق ينج سانتىمتر آب ايستابى روى سطح

\footnotetext{
${ }^{1}$ Ghassemi-Golezani

${ }^{2}$ Shahi
} 
فلاح شمسى و همكاران: تأثير تنش خشكى مرحله زايشى بر ويزَّى هاى جوانهزنى بذر زنوتيّهاى بومى...

\begin{tabular}{|c|c|c|c|c|}
\hline \multicolumn{5}{|c|}{ جدول ا- ويزگ هاى زنوتيڤهاى برنج مورد آزمايش } \\
\hline تحمل به تنش خشكى * & منشأ & ويثزى & رنوتيب & شماره \\
\hline 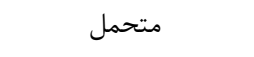 & 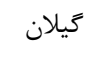 & 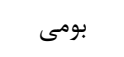 & على كاظمى & 1 \\
\hline 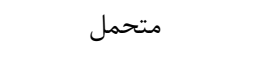 & 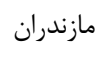 & 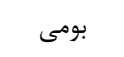 & 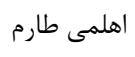 & r \\
\hline 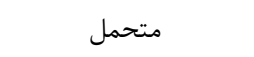 & 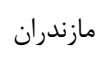 & اصلاحشده & 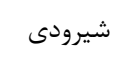 & r \\
\hline متحمل & مازندران & اصلاحشده & ندا & r \\
\hline 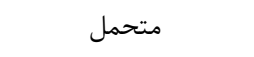 & 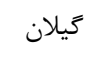 & اصلاحشده & كيلانه & $\Delta$ \\
\hline 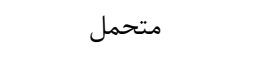 & 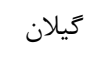 & اصلاحشده & 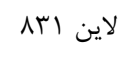 & 4 \\
\hline حساس & كَيلان & اصلاحشده & كوهر & v \\
\hline
\end{tabular}

كاغذهاى پيجيده شده با قطر حدود جهار سانتى متر در

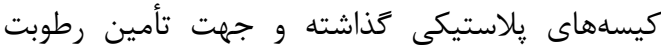
كافى براى رشد به پِلاستيك حاوى كاغذ صافى، مقدار

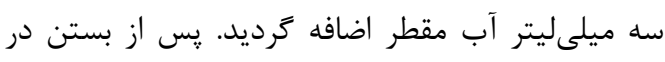

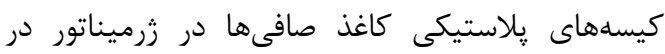

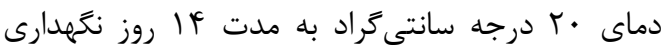

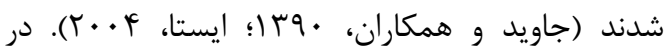

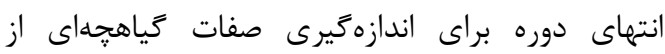
بذرهاى رشد يافته در كاغذ صافى استفاده شد. ريشهجه و ساقه جه از بذر جدا و طول ريشه جه، ساقه گياهجه با خطكش و برحسب ميلىمتر اندازهزيرى شدند. براى تعيين وزنتر و خشك ريشه

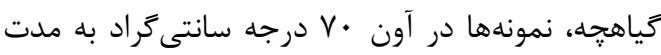

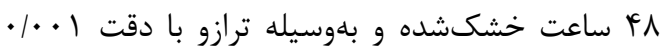

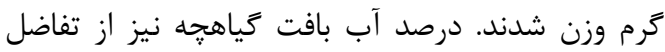
وزنتر و خشك گياهجه تقسيم بر وزنتر زياهجه ضربدر . . . محاسبه شد. براى محاسبه ضريب آلومترى نيز

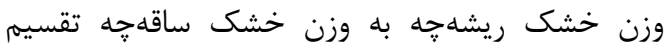
گرديد. آزمون طبيعى بودن دادهها، تجزيه دادهها و و مقايسات گروهى با نرمافزار SAS نسخه

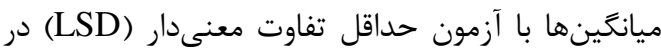

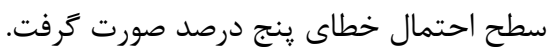

\section{نتايج و بحث}

بر اساس نتايج تجزيه واريانس، بين زنوتيڤها در تمامى صفات بهجز درصد جوانهنى، شاخص بنيه

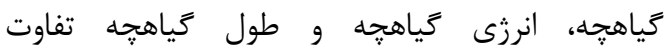

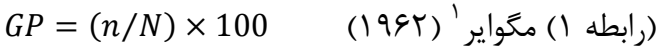

$$
\begin{aligned}
& \text { GP = درصد جوانهزنى } \\
& G I=\sum n_{t} / t \quad(199 T) \text { (رابطه r) (19) مخواير } \\
& \text { GI = سرعت جوانهزنى } \\
& \text { (رابطه r) عبدالباكى و اندرسون' ( } \\
& \mathrm{VI}=\mathrm{GP} \times \mathrm{PL}
\end{aligned}
$$

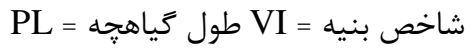

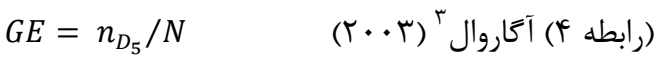

$$
\begin{aligned}
& n_{D_{5}} / N
\end{aligned}
$$$$
\text { انرزى جوانهزنى = }
$$

(رابطه ه) خليلى اقدم و همكاران (| وبا )

$R_{50}=1 / D_{50}$

(رابطه 9) خليلى اقدم و همكاران ( ا وبا )

$$
G U=D_{10}-D_{90}
$$

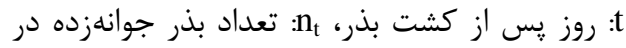

$$
\text { روز t، N تعداد كل بذرها }
$$

\section{آزمون گياهجهاى}

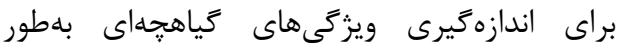

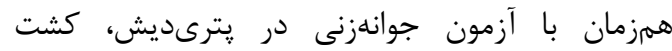
بذرهاى برنج در كاغذ صافى انجام شد. بدين منظور ابتدا

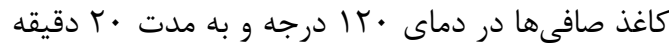
اتوكلاو شدند. سيس بعد از مرطوب كردن كاغذ صافى،

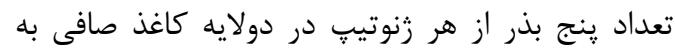

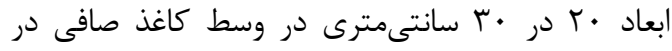

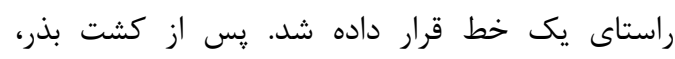

\footnotetext{
${ }^{1}$ Maguire

${ }^{2}$ Abdul-Baki and Anderson

${ }^{3}$ Agarwal
} 
طبيعى ثبت گرديد. مقايسه بذرهاى حاصل از شرايط طبيعى زنوتيڤهاى مورد بررسى نشان داد كه بيشترين

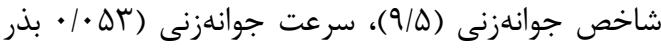

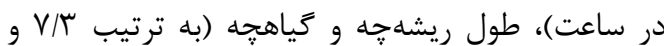

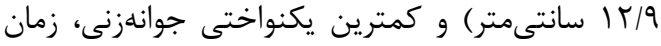

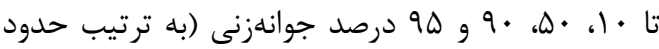

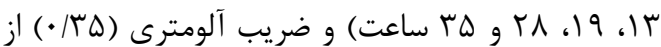
رقم شيرودى به دست آمد. از بين بذرهاى تنش ديده، براى بذر رقم على كاظمى بيشترين شاخص جوانهزنى

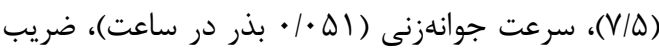

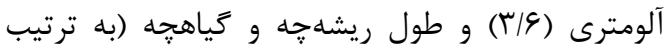

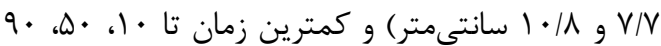

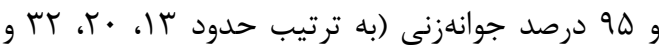

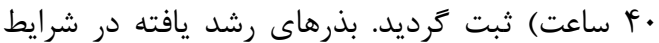
طبيعى رقم ندا بيشترين ضريب آلومترى را داشتند

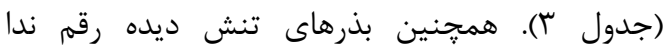
بيشترين طول ريشه קه و طول كياهجه را داشتند و از بذرهاى تنش ديده اهلمى طارم و شيرودى كمترين

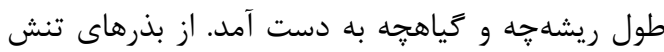
ديده لاين اسمى كمترين وزنتر و خشك ريشهاتهه، ساقهجه و كياهجه و از بذرهاى رشد يافته آن تحت شرايط طبيعى بيشترين وزنتر و خشك براى ريشه

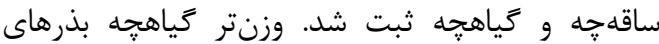
تنش ديده رقم كيلانه نيز در سطح معنى دارى يكسانى

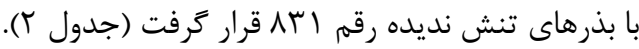

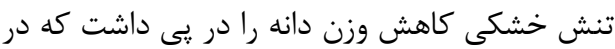
همين زمينه كاهش حدود نه درصدى وزن هزار دار دانه برنج تحت تأثير تنش كمبود آب توسط صفائى حدائى جائى كار

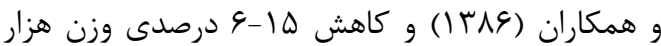
دانه برنج در شرايط • F درصد رطوبت ظرفيت زراعى

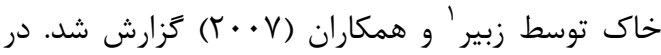

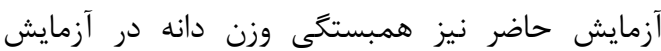
مزرعهاى و بيشتر صفات جوانهزنى مثبت و غير معنى دار

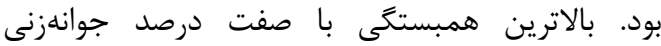

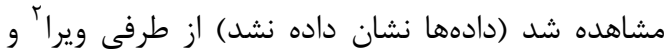
همكاران (1997)، در آزمايشى روى سويا بيان كردند كه دهان

${ }^{1}$ Zubaer

${ }^{2}$ Vieira
معنىدارى (P0.01) مشاهده شد. اعمال تنش خشكى در مرحله زايشى نيز جز صفات درصد جوانهزنى، شاخص الهص

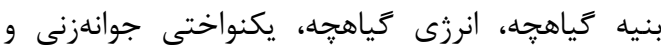

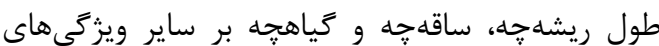
جوانهزنى اندازهكيرى شده اثر معنىدارى (P>0.01) داشت. برهمكنش زنوتيٍ و تنش خشكى مرحله زايشى نيز بر همكى صفات موردبررسى بهاجز درصد جوانهزنى، شاخص بنيه كياهجه، انرزى جوانهزنى و طول ساقهاته در سطح احتمال يك درصد معنىدار بود. اثر تنش خشكى آزمايش مزرعهاى نيز بر وزن هزار دار دانه معنى دار بود و كاهش حدود V درصدى را به دنبال داشت (جدول

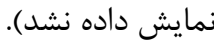
مقايسه ميانكين برهمكنش تنش خشكى مرحله زايشى و رنوتيب نشان داد كه بيشترين ميزان صفت شاخص جوانهزنى از بذرهاى رقم شيرودى رشد يافته در شرايط طبيعى و كمترين مقدار از اهلمى طارم حاصل از از

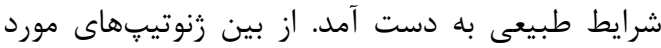
بررسى دو رقم شيرودى و على كاظمى رشد يافته تحت

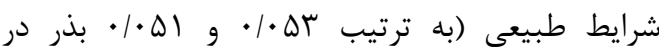
ساعت) بالاترين سرعت جوانهزنى و بذر لاين ابرم تنش ديده كمترين سرعت جوانهزنى را داشتند. بذرهاى لاين ابم تنش ديده يكنواختى جوانهزنى (حدود • إساعت)

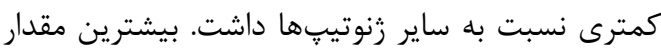

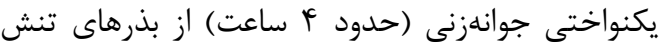
نديده شيرودى ثبت شد. نتايج مقايسه ميانگين نشان

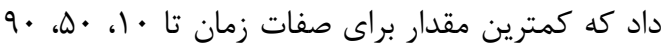
و ه9 درصد جوانهزنى از بذرهاى رقم شيرودى تنش دان

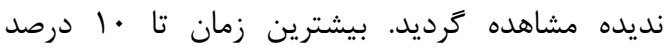
جوانهزنى از بذرهاى تنش نديده رقم كوهر و بيشترين

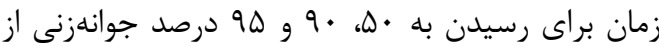

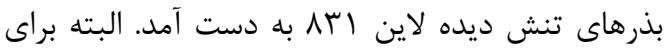
صفت زمان تا هو درصد جوانهزنى بذرهاى رقمم اهلمى دائى طارم در هر دو شرايط تنش ديده و طبيعى و بذرهاى

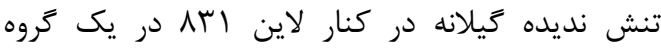
آمارى (كلاس a) قرار داشتند. از بررسى ميانكين درصد آب بافت كياهحه براى زنوتيبها آشكار شد كه بيشترين مقدار اين صفت از بذرهاى تنش نديده رقم كيلانه و

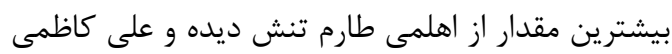


جدول r- مقايسه ميانكَين ويثَى هاى جوانهزنى رُنوتيبهاى برنج مورد آزمايش

\begin{tabular}{|c|c|c|c|c|c|c|c|c|c|c|}
\hline ضريب & دَآب بافت & 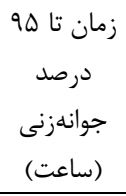 & جو زوان درصد & 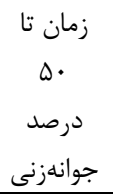 & • زمان اندان & جوانوزنى & جرانهزنى & شوانهزنى & شرايط & رنوتيب \\
\hline$\cdot / r \cdot d$ & $r q / r f$ & $\Lambda T / r c d$ & $99 / \cdot f$ & $r l / / g h$ & Ir/qed & s/D $/ \mathrm{c}-\mathrm{f}$ & $.1 .49 a b c$ & $\mathrm{~V} / \mathrm{A} \cdot \mathrm{bc}$ & $\mathrm{NS}$ & على \\
\hline$r / \Delta \wedge b$ & $\Delta s / Y d$ & $f \cdot / / g f$ & $r / / 9 i$ & $19 / \mathrm{Vgh}$ & $1 r / \omega \mathrm{e}$ & $r / r V f g$ & $\cdot / \cdot \Delta \mid a b$ & $V / \Delta F b c$ & DS & كاظمى \\
\hline $1 / 49 c$ & Vq/Aab & $1 r \cdot / v a$ & $\mid r \Delta / r b$ & $9 \Delta / 9 \mathrm{bc}$ & $\Leftrightarrow \varphi / \Delta \mathrm{a}$ & $\Lambda / V v a b c$ & $\cdot / 1$ bef & r/A^h & NS & اهلمى \\
\hline$\cdot / 1 \Delta \mathrm{d}$ & $r \varepsilon / \Delta \mathrm{f}$ & $\mid \& \varepsilon / \omega \mathrm{a}$ & $\mid r \omega / r a$ & $q r / f b c$ & $\mid q \varepsilon / 4 a$ & N/rsa-d &.$/ .19 \operatorname{def}$ & $r / l q \mathrm{gh}$ & DS & طارم \\
\hline$\cdot / r \Delta \mathrm{d}$ & $q \mathrm{~V} / \Delta \mathrm{C}$ & $r F / \Lambda g$ & $T V / \& i$ & IN/vh & $1 \pi / \pi \mathrm{e}$ & $r / v \cdot g$ &.$/ \cdot \Delta r a$ & $9 / \Delta \cdot a$ & NS & \multirow[b]{2}{*}{ شيرودى } \\
\hline - /Arcd & $98 / \mathrm{Ac}$ & $99 / \pi \mathrm{de}$ & $99 / 0 \mathrm{f}$ & $\mid \psi \psi / \cdot e$ & |Q/丿ed & $V / / \& b-e$ &.$/ . r F d$ & $\Delta /$ rAde & DS & \\
\hline Ir/fra & $V \varepsilon / \& b$ & $\varepsilon \mathrm{V} / \Delta \mathrm{de}$ & 91/4gf & TV/qf & $\mid f /$ red & s/V Vb-e &.$/ . r v c$ & s/Nacd & NS & \multirow{2}{*}{ ندا } \\
\hline$\cdot \mid \kappa \Delta d$ & $\Delta \& / \varphi \mathrm{d}$ & $9 \mathrm{~V} / \mathrm{rde}$ & $\Delta F / V g$ & $r F / \Delta \mathrm{gf}$ & $\mid f /$ ved & g/rydef &.$/ .4 r b c$ & $V / r q b c$ & DS & \\
\hline.$/ \varphi v d$ & vQ/qa & $\mid q V / r a$ & $\mid r \varepsilon / \Delta a$ & $9 \Delta / \& \mathrm{bc}$ & rT/FC & $9 / \cdot \cdot a b$ & $.1 .19 \mathrm{def}$ & $r / \Delta \vee f g h$ & NS & \multirow{2}{*}{ كيلانه } \\
\hline $1 / 49 \mathrm{c}$ & Vद/ & $1 \cdot \cdots / \wedge b c$ & $11 / 9 \mathrm{e}$ & $\Delta \Delta / / d$ & $\Gamma / / r c$ & $V / F \Delta b-e$ & $\cdot / \cdot$ ride & $\boldsymbol{r} / \boldsymbol{q} \mid \mathrm{efg}$ & DS & \\
\hline $1 / 4 r c$ & $F r / \Delta \mathrm{e}$ & $1 \cdot r / r b$ & $9 \Psi / \cdot d$ & $91 / \mathrm{Vc}$ & $\mathrm{IV} / \mathrm{d}$ & N/ब৭a-d &.$/ .19 \mathrm{def}$ & F/Vvef & NS & \multirow{2}{*}{$\Lambda \mu_{1}$} \\
\hline . & $V r / r b$ & $\mid f \varepsilon / 9 \mathrm{a}$ & $1 r q / 1 a$ & $\wedge \varepsilon / \cdot \mathrm{a}$ & $r q / \Delta b$ & $1 \cdot / r q a$ &.$/ .1 r f$ & $r / r q f g h$ & DS & \\
\hline - / Vrcd & $\Delta r / v d$ & $\Delta F / V$ ef & $r \Delta / r h$ & $r \cdot / 9 \mathrm{gh}$ & $r \Delta / r a$ & D/G refg & $.1 . \uparrow q a b$ & N/rqab & NS & \multirow{2}{*}{ كوهر } \\
\hline . & Vq/qab & $\mid \mathrm{rv} / \Delta \mathrm{a}$ & $11 \cdot 1 \cdot \mathrm{c}$ & $q V / r b$ & $1 \mathrm{r} / \mathrm{ve}$ & V/Asb-e & $\cdot / 1 \Delta \mathrm{ef}$ & $r / l \Delta g h$ & DS & \\
\hline
\end{tabular}

جدول r (ادامه)

\begin{tabular}{|c|c|c|c|c|c|c|c|c|c|}
\hline وزاقن خشك & وزن ريش & 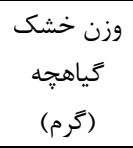 & 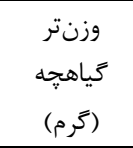 & 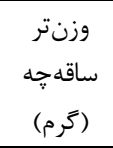 & 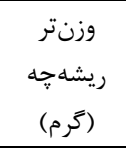 & طول كياهجه & طول ريشه جه & شرايط & زنوتيب \\
\hline$\%$ vefg & $\cdot / \cdot$ Vefg &.$/ \cdot 1 \mathrm{dd}$ & $.1 .19 \mathrm{de}$ &.$/ .19 a$ &.$/ .19 \mathrm{de}$ & $1 \cdot 19 \cdot b c$ & $\Delta /$ rode & NS & على \\
\hline$\cdot \cdot \wedge \mathrm{e}$ & $\cdot / \cdot \wedge \mathrm{e}$ & $\cdot / \cdot \wedge \mathrm{e}$ &.$/ .1 \wedge$ de & $\cdot / \cdot r f g$ & $\cdot / \cdot 1 \wedge$ de & $1 \cdot / \wedge r b c$ & $V / V \cdot a b$ & DS & كاظمى \\
\hline .. TVab & ./.Trab & $.1 .1 \mathrm{rcd}$ & $\cdot / \cdot \Delta r a$ & $\cdot / \cdot \Delta \mathrm{d}$ &.$/ \cdot \Delta r a$ & $11 / 4 \cdot b c$ & s/ Ved & NS & اهلمى \\
\hline.$/$. vefg & $\cdot / \cdot$ vefg & $.1 .14 \mathrm{c}$ & $.1 .19 \mathrm{de}$ &.$/ \cdot 1 \mathrm{fb}$ &.$/ .19 \mathrm{de}$ & $1 / 9 \cdot \mathrm{c}$ & reff & DS & طارم \\
\hline$\%$. & $\cdot / \cdot \lambda \mathrm{e}$ &...$\varphi \mathrm{f}$ & $.1 .19 \mathrm{cde}$ &... $\mathrm{Fe}$ & $.1 .19 \mathrm{cde}$ & Ir/AVab & V/rybc & NS & \multirow{2}{*}{ شيرودى } \\
\hline.. .4 efg & $\cdot / \cdot$ vefg & $\cdot / \cdot \mathrm{kgh}$ &.$/ .1 \mathrm{re}$ & $\cdot / \cdot \cdot r f g$ &.$/ .1 \mathrm{re}$ & $\Lambda / r \cdot c$ & $r / \Delta F f$ & DS & \\
\hline.$/ . \vee f g$ &.$/ .9 \mathrm{gf}$ & $\cdot / \cdot r h$ &.$/ .1 \mathrm{re}$ & $\cdot / \cdot r g$ & $.1 .1 \mathrm{re}$ & $1 \cdot / v \vee b c$ & F/ardef & NS & \\
\hline $.1 .19 \mathrm{c}$ & $\cdot 1 \cdot 1 \mathrm{Vc}$ & $\cdot / \cdot 1 \Delta \mathrm{b}$ & $\cdot / \cdot r \Delta b$ & $\cdot / \cdot 1 \mathrm{~h}$ & $\cdot / \cdot r \Delta b$ & I & N/Ara & DS & \\
\hline $.1 .1 \mathrm{rd}$ &.$/ .1 \mathrm{rd}$ & $\cdot / \cdot \Delta \mathrm{fg}$ & $.1 . \mathrm{rfcd}$ & $\cdot \cdot r \mathrm{rf}$ & .. rfed & $1 . / 9 \mathrm{rbc}$ & $F / q)$ def & NS & ي يلانه \\
\hline$\cdot / \cdot r \& b$ & $.1 . r s \mathrm{~b}$ & $.1 .1 \mathrm{rcd}$ & $.1 . \Delta r a$ & $\cdot \cdot \Delta \mathrm{d}$ & $.1 . \Delta r a$ & $N / \Delta r c$ & r/rief & DS & \multirow{2}{*}{ A } \\
\hline$\cdot / \cdot r 9 a$ & $.1 \cdot r 9 a$ & . & $\cdot / \cdot \Delta \wedge \mathrm{a}$ &.$/ \cdot 1 \mathrm{fb}$ & $\cdot / \cdot \Delta \wedge \mathrm{a}$ & $9 / 4 r b c$ & f/rqef & NS & \\
\hline$\cdot \cdots \Delta g$ & $.1 . .9 \mathrm{~g}$ & $\cdot / . r h$ & $.1 .11 \mathrm{e}$ & $\cdot / \cdot r g$ & $.1 .11 \mathrm{e}$ & $11 / \pi v b c$ & $\Delta / \mathcal{F} \cdot \mathrm{de}$ & DS & \multirow{3}{*}{ كوهر } \\
\hline $.1 .1 \mathrm{fd}$ & $.1 .19 \mathrm{c}$ & $.1 .14 \mathrm{~cd}$ &.$/ \cdot r \wedge b c$ & $\cdot \cdot v_{c}$ & $\cdot / \cdot r \wedge b c$ & $11 / 9 \cdot a b c$ & $k / q)$ def & NS & \\
\hline$\% \cdot$ vefg & $\cdot / \cdot$ vefg & $\cdot / \cdot r g h$ &.$/ .1 \Delta$ de & $\cdot / \cdot r r g$ &.$/ .1$ de & $1 \pi / r \cdot a b$ & D/rade & DS & \\
\hline
\end{tabular}


كمتر ارقام بومى در برابر ارقام اصلاحشده (جدول f)

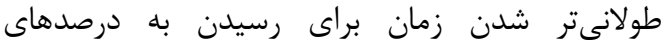

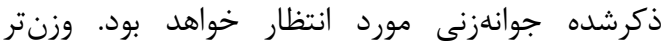

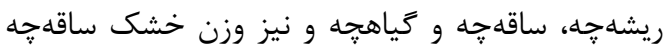
ارقام بومى بيشتر از ارقام اصلاحشده بود. مقايسه

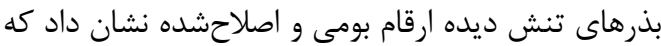

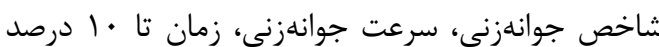

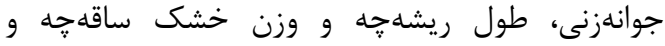
كياهجه ارقام بومى نسبت به ارقام اصلاحشده بيشتر بود.

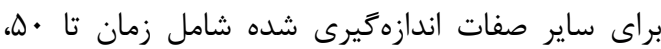
•9 و ه9 درصد جوانهزنى، درصد آب بافت كياهجه، طول ساقه קه و وزنتر ريشهجه، ساقهجه و گياهجه و و وزن خشك ريشه קه مقدار كمترى از ارقام بومى نسبت به ارقام اصلاحشده ثبت شد. مقايسه بذرهاى تنش ديده با بذرهاى تنش نديده ارقام اصلاحشده نشان داد كه در اثر تنش خشكى مرحله زايشى صفات شاخص جوانهزنى، وزنتر و خشك ريشه קه، ساقه קه و كياهجه كاهش يافتند. از طرفى، تنش خشكى باعث شد شد كه صفات روز

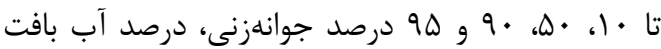
كياهجه و ضريب آلومترى در بذرهاى تنش ديده نسبت

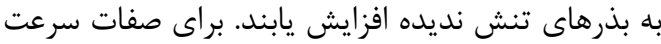
جوانهزنى، طول ريشه קه و ساقهجه، وزنتر ريشه ساقهجه تغييرى بين ارقام تنش ديده و تنش نديده مشاهده نشد. در مورد ارقام بومى تنش خشكى بنى مرحله زايشى سبب شد تا نسبت به بذرهاى تنش نديده زمان

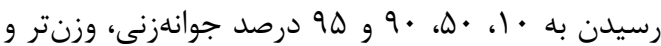
خشك ريشهجه، ساقه קه و گياهجه كاهش يابد. از ساير

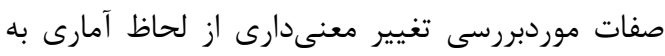
دليل رشد در شرايط تنش مشاهده نكرديد (جدول ب).

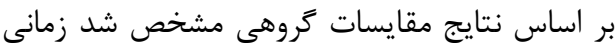

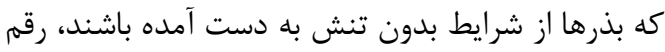

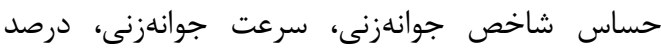

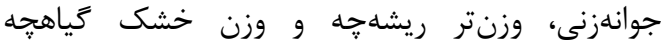
بيشترى نسبت به ارقام متحمل داشتند در حالى كه از

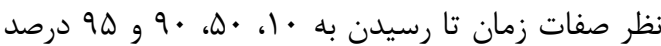
جوانهزنى، ضريب آلومترى، طول ريشه קه و ساقه تهد، وزنتر ريشه קه و ساقهجه مقدار كمترى براى اين ارقام در قياس با ارقام متحمل ثبت شد. از سوى ديخر از
تنش خشكى از طريق تأثير مستقيم بر متابوليسم بذر،

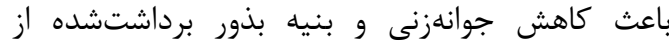

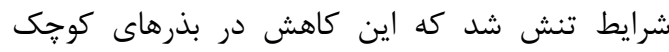

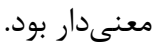
در كزارشى ديكر مشاهده شد كه درصد جوانهزنى،

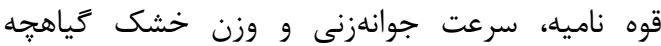
بذرهاى باقلا در اثر قطع آب مرحله گَلدهى و ور شر شدن

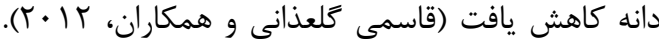
در همين زمينه، ارزيابى اثر اندازه بذر و تنش آبى بر براني

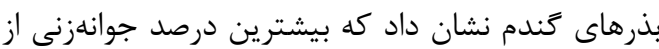

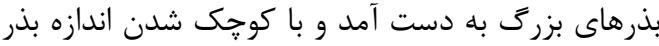
ميزان جوانهزنى كاهش يافت. طول ريشه קه، ساقهجه و و

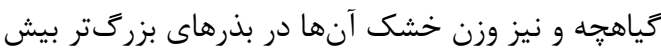
از ساير بذرها (متوسط و كوجك) بود. سرعت جوانهزنى

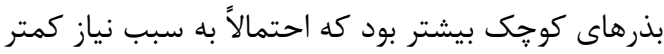

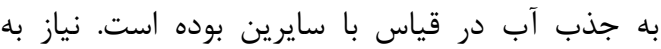
جذب آب بيشتر در بذرهاى بزرى احتمالاً منجر بلهرف

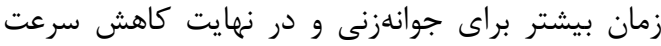

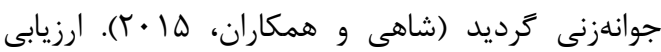
خصوصيات جوانهزنى بذرهاى كندم حاصل از تنش

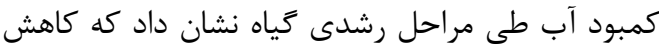
در تمامى صفات جوانهزنى جز نسبت ساقهاجه به به ريشهجه و ميانكين زمان جوانهزنى از اين بذرها حاصل

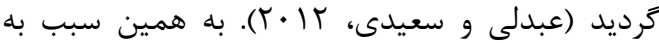

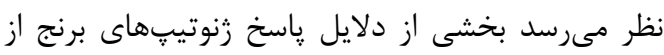

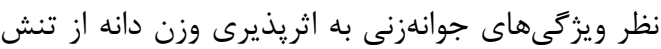
خشكى مرحله زايشى مرتبط باشد.

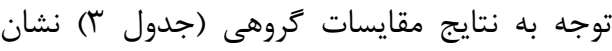
مىدهد كه در بين بذرهاى رشد يافته تحت شرايط طبيعى (بدون تنش) ارقام بومى شاخص جوانهزنى

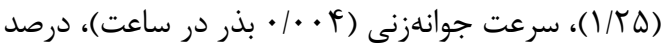

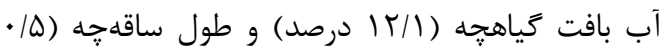
سانتىمتر) كمترى نسبت به ارقام اصلاحشده داشتند.

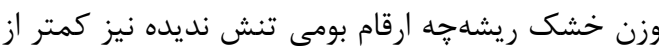
ارقام اصلاحشده تنش نديده بود؛ اما وزن خشك كياهجه تئه

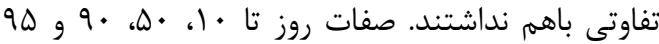
درصد جوانهزنى در ارقام بومى بيشتر از ارقام اصلاحشده

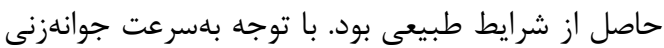


روى كياه برنج آيلند تحت شرايط ديم' و آبيارى بارانى

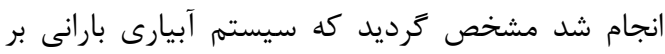

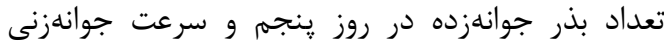

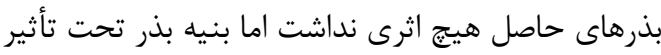
قرار كرفت و در هر دو شرايط ديم و آبيارى، بنيه بذر بدري

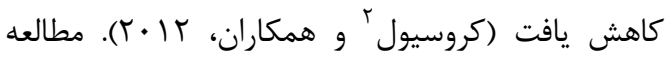

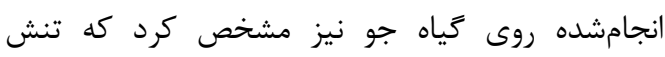
خشكى انتهاى دوره، بر بنيه بذر بيشتر از جوانهزنى

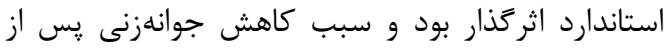

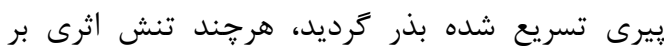

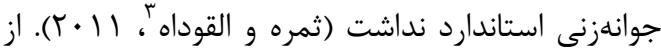

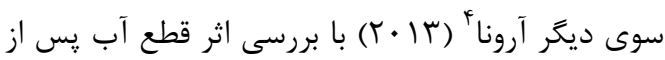

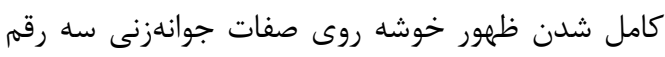

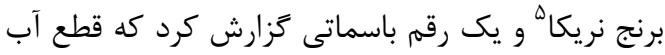
بر صفات جوانهزنى روى كاغذ صافى، طول كياهجه و

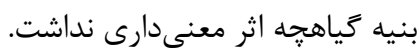

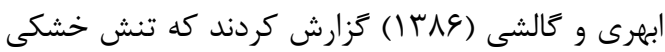
قبل از تردهافشانى تا مرحله برداشت و و بعد از

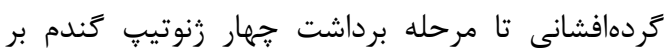

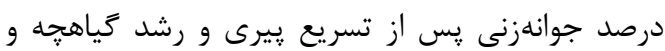
همجنين حداكثر جوانهزنى اثر كاهشى داشته و زمان تان تان شروع جوانهزنى و رسيدن به • ا درصد حداكثر جوانه زنى آن نسبت به شاهد را افزايش داده است. همجنين تنش خشكى در مرحله ير شدن دانه در

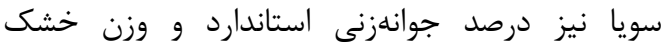
كياهجه را به ترتيب ه و و آ ال درصد كاهش داد. بين

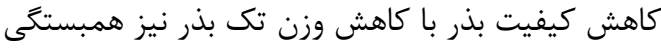
مشاهده شد (دورنبوس "و و همكاران، 1919 (19). يك اثر مهمم كمبود آب روى دريافت مواد مغذى توسط ريشه ريشه و انتقال به ساقه است كه تركيب شيميايى بذر را تغيير

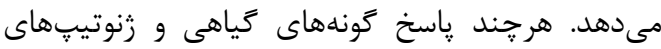
مختلف يك كونه متفاوت است اما بهطور كلى تنش

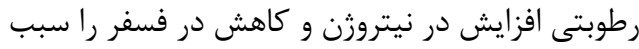

\footnotetext{
${ }^{1}$ Rainfed

${ }^{2}$ Crusciol

${ }^{3}$ Samarah and Alqudah

${ }^{4}$ Aruna

${ }^{5}$ NERICA (New Rice for Africa)

${ }^{6}$ Dornbos
}

مقايسه بذرهاى تنش ديده رقم حساس و متحمل مشخص كرديد كه تنش خشكى مرحله زايشى سبب تهن

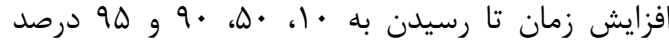

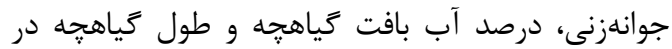
رقم حساس نسبت به ارقام متحمل كرديد. در حالى دالى كه شاخص جوانهزنى، سرعت جوانهزنى، ضريب آلومترى،

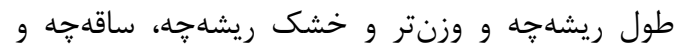
كياهجه كمترى نسبت به ارقام متحمل داشتند. از طرفى نق مقايسه ارقام متحمل نشان داد كه تنش مرحله زايشى

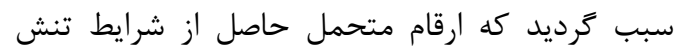

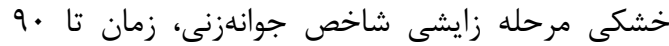

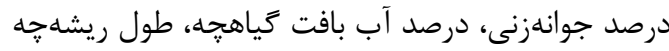
و وزنتر و خشك ساقهجه كمترى نسبت به زمانى كه دابه بذرهاى تحت شرايط طبيعى رشد يافتهاند داشته است؛

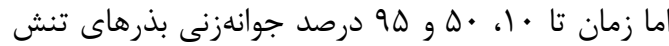
ديده بيشتر از ارقام متحمل حاصل از شرايط شاهد بود.

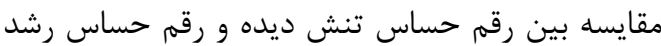
يافته در شرايط شاهد حاكى از آن است كه تنش دانش

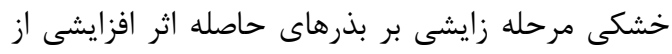

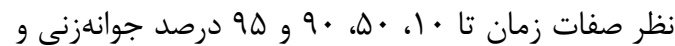

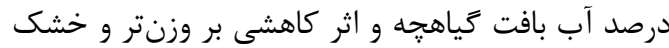

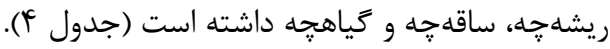
نتايج جوانهزنى بذرهاى كندم نان رشد يافئن شرايط تنش خشكى كه با استفاده از كلريد يتاسيم جهار درصد اعمال كرديد نشان داد ارقام متحمل درئل درصد جوانهزنى، طول كلئويتيل، طول كياهجه، وزن تر ساقه

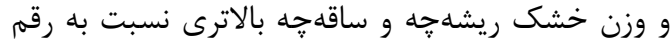
حساس و نيمهمتحمل داشتند. در حالى كه بالاترين

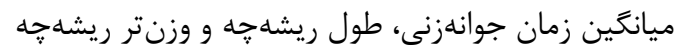
از رقم حساس به تنش به دست آمد. براى بذرهاى تنش نديده (شاهد) تعداد ريشه، طول كلئويتيل، طول

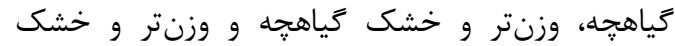
ريشهجه بيشترى از بذرهاى تنش ديده ثبت كرديد. در مقابل بذرهاى تنش ديده مقدار جذب آب بالاتر و درصد دئد جوانهزنى بالاترى نسبت به شاهد داشتند كه علت اين

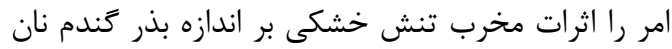

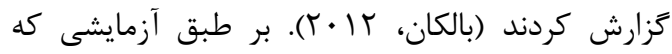




\begin{tabular}{|c|c|c|c|c|c|c|c|c|}
\hline \multicolumn{9}{|c|}{ جدول r- مقايسه ميانكين گروهى صفات موردبررسى در آزمايش بين ارقام بومى و اصلاحشده } \\
\hline ضريب آلومترى & دربافت & جوان & زمان تا • جرانهز & زمان تا • درانه & زمان تا · 1 زوصد & 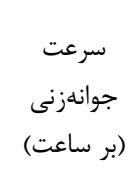 & جوانهزنى & كروها \\
\hline$(+\cdot / 14)^{* *}$ & $(-|Y /| r)^{* *}$ & $(+r \Delta / r I)^{* *}$ & $(+\Gamma \digamma / \Gamma \Delta)^{* *}$ & $(+\boldsymbol{Y} / \Lambda T)^{* *}$ & $(+11 / 9 r)^{* *}$ & $(-\cdot / \cdot r)^{* *}$ & $(-1 / \Gamma \Delta)^{* *}$ & (1) \\
\hline$(-1 / 4 r)^{* *}$ & $(-r \wedge / \vee \Lambda)^{* *}$ & $(-11 / \cdot r)^{* *}$ & $(-9 / \wedge \Delta)^{* *}$ & $(-1 r / \Lambda \cdot)^{* *}$ & $(+\cdot / 9 \cdot 9)^{* *}$ & $(+\cdot / \cdot 9)^{* *}$ & $(+\cdot / \Delta 9)^{* *}$ & $(r)$ \\
\hline$(+Y / 91)^{* *}$ & $(+\varepsilon / 4 V)^{* *}$ & $\left(+r r / \cdot r^{*}\right)^{* *}$ & $(+\mid V / \varepsilon Y)^{* *}$ & $(+19 / 49)^{* *}$ & $(+1 \cdot / \wedge V)^{* *}$ & $(-\cdot / \cdot 1 \cdot)^{\mathrm{ns}}$ & $(-1 / \wedge \Gamma)^{*}$ & (ए) \\
\hline$(+1 / \cdot r)^{\mathrm{ns}}$ & $(-1 \cdot / 19)^{* *}$ & $(-1 Y / r \cdot)^{*}$ & $(-\mid r / \Delta V)^{*}$ & $(-r / / r)^{* *}$ & $(-\cdot / 1 \mathrm{Fr})^{* *}$ & $(+\cdot / \cdot \cdot r)^{\mathrm{ns}}$ & $(+\cdot / \cdot 1)^{\mathrm{ns}}$ & $(f)$ \\
\hline كَياهجه (كرم) خشك & ساقه & وزن خشك ريه & وزياهجه & ساقه جه & رزيش & 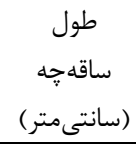 & (سانتى ريشه ) & كروها \\
\hline$(+\cdot / \cdots \cdot r)^{* *}$ & $(+\cdot / \cdot \cdot \Delta)^{* *}$ & $(-\cdot / \cdot r)^{* *}$ & $(+\cdot / \cdot \cdot v)^{*}$ & $(+\cdot / \cdot r)^{* *}$ & $(+\cdot / \cdot r)^{* *}$ & $(-\cdot / 4 q)^{* *}$ & $(+\cdot|f| f)^{\mathrm{ns}}$ & (1) \\
\hline$(+\cdot / \cdot r r)^{* *}$ & $(+\cdot / \cdot \cdot 4)^{* *}$ & $(-\cdot / \cdot r)^{* *}$ & $(-\cdot / \cdot \cdot 9)^{* *}$ & $(-\cdot / \cdot \cdot \Delta)^{* *}$ & $(-\cdot / \cdot \cdot \Delta)^{* *}$ & $(-\cdot / 99)^{\mathrm{ns}}$ & $(+\cdot / r T \varphi)^{*}$ & $(r)$ \\
\hline$(-\cdot / \cdot \cdot r)^{* *}$ & $(-\cdot / \cdot r)^{* *}$ & $(-\cdot / \cdot \cdot 1)^{* *}$ & $(-\cdot / \cdot r)^{\mathrm{ns}}$ & $(-\cdot / \cdot 1)^{\mathrm{ns}}$ & $(-\cdot / \cdot r)^{\mathrm{ns}}$ & $(+\cdot / \cdot \boldsymbol{f})^{\mathrm{ns}}$ & $(+\cdot / 191)^{\mathrm{ns}}$ & (r) \\
\hline$(-\cdot / \cdot \cdot 1)^{* *}$ & $(-\cdot / \cdot r)^{* *}$ & $(-\cdot / \cdot \cdot 1)^{* * *}$ & $(-\cdot / \cdot 11)^{* *}$ & $(-\cdot / \cdot 1 \cdot)^{* *}$ & $(-\cdot / \cdot \cdot 9)^{* *}$ & $\left(-\cdot / \mathbb{F r}^{\mathrm{ns}}\right.$ & $(+\cdot / \cdot 1 \cdot)^{\mathrm{ns}}$ & $(\mathcal{F})$ \\
\hline
\end{tabular}

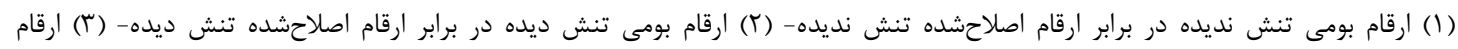

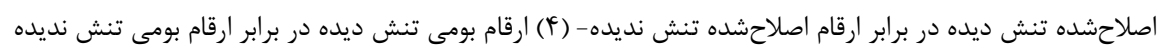

اسيد را در بيى دارد. از سوى ديخر تركيب بذر بر ميزان

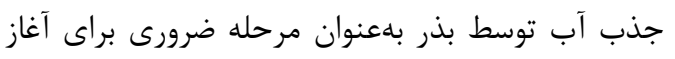

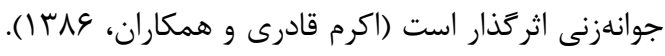
كاهش مواد معدنى در بذر با رشد ضعيف بذر و كياهجه

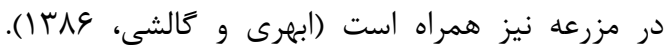

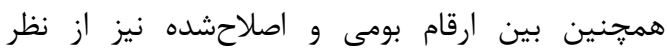

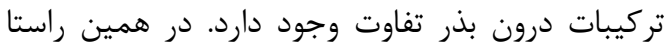

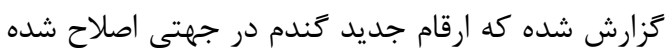

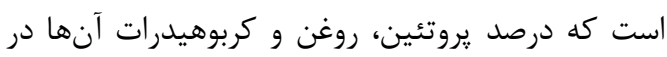
مقايسه با ارقام قديمىتر بيشتر است (اكرم قادرى و

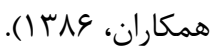

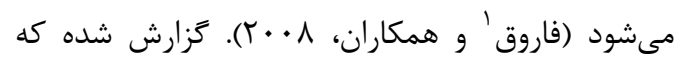

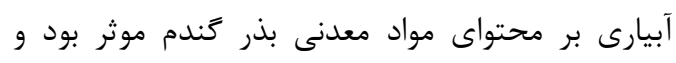

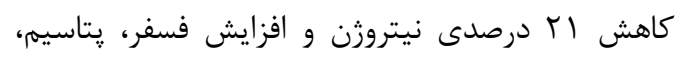

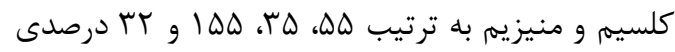

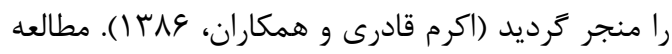
اثر تنش خشكى بر برخى تركيبات غذايى دانه برنج نيز

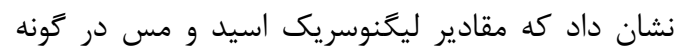

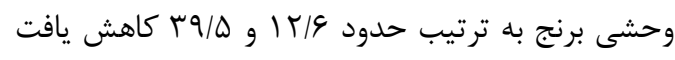

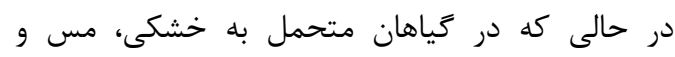

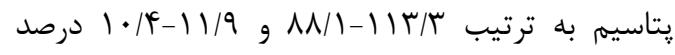

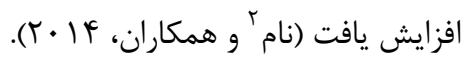

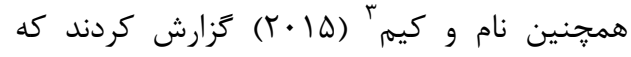
تنش خشكى افزايش ميزان متيونين، فنيل آلآنين،

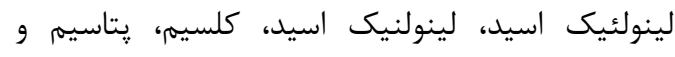

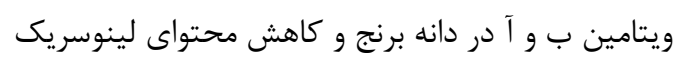

\footnotetext{
${ }^{1}$ Farooq

${ }^{2} \mathrm{Nam}$

${ }^{3} \mathrm{Nam}$ and Kim
} 


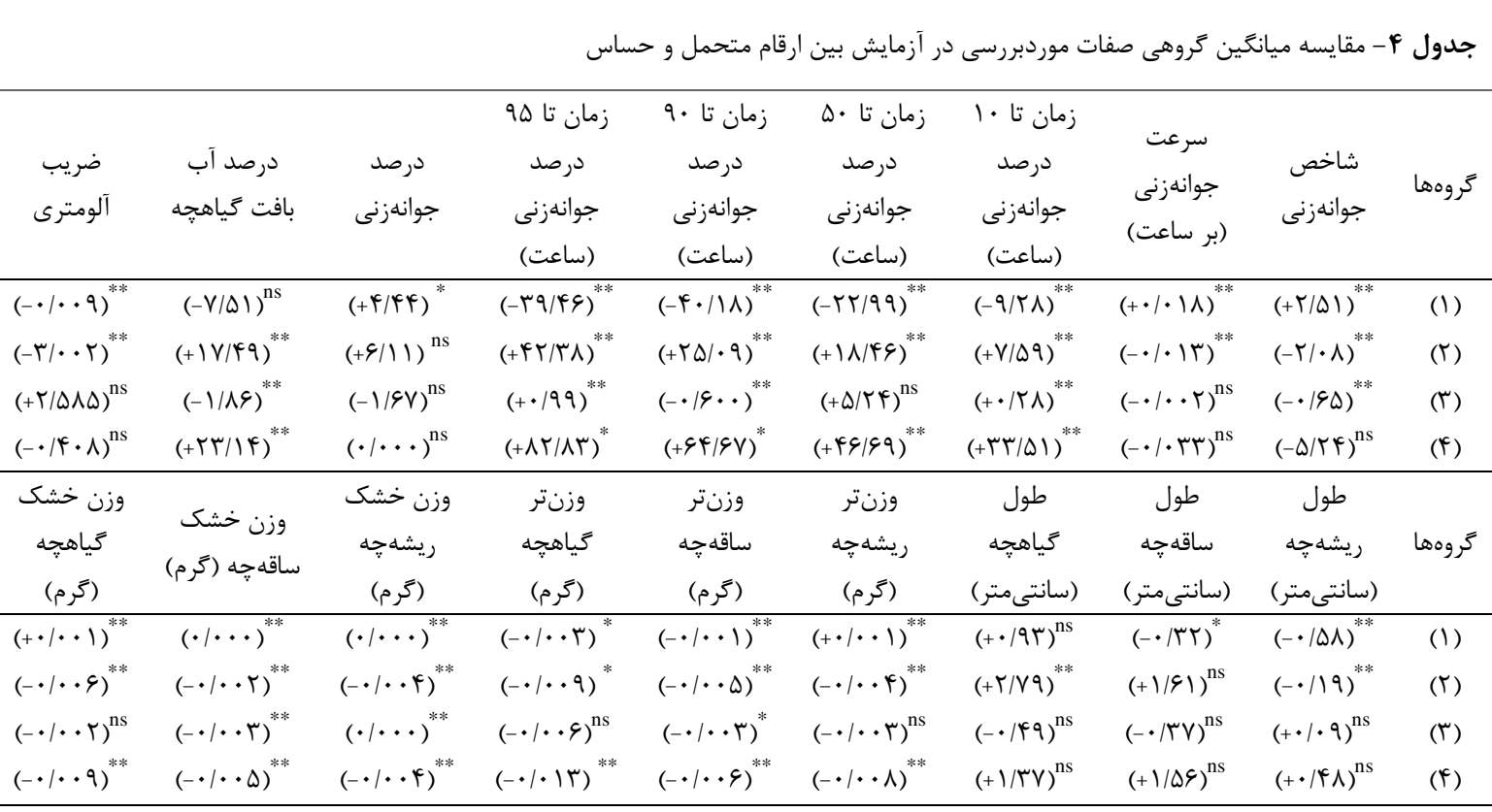

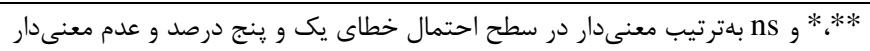

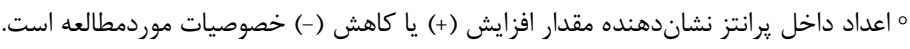

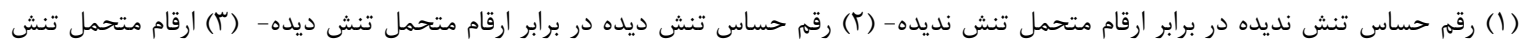

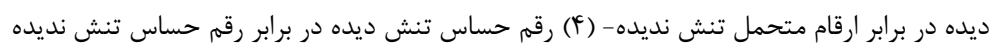

متحمل مشخص كرديد كه بذرهاى تنش ديده رقم

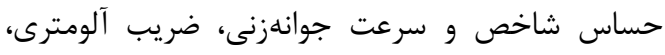

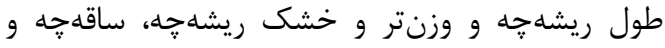

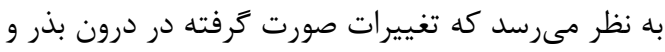

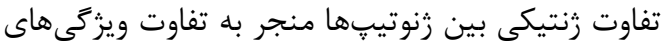

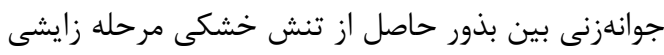
و بذور رشد يافته در شرايط بدون تنش كرديد.

\section{سياسگزارى}

بدينوسيله از موسسه تحقيقات برنج كشور در رشت

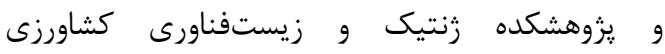
طبرستان، دانشخاه علوم كشاورزى و منابع طبيعى سارى زئن

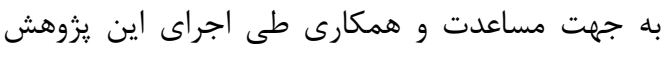

$$
\text { قدردانى مىشود. }
$$

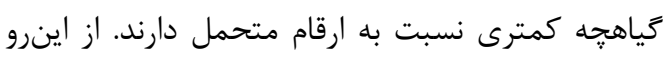

\section{نتيجه كيرى}

خنانجه از نتايج آزمايش حاضر آشكار شد تنش

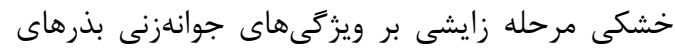

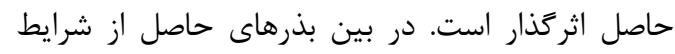

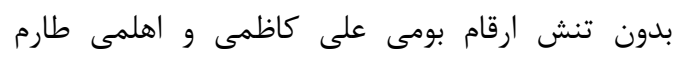

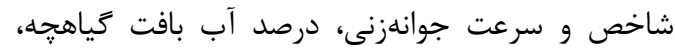

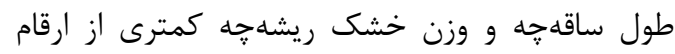

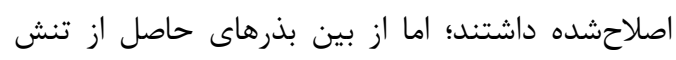

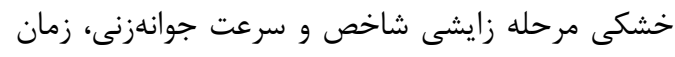

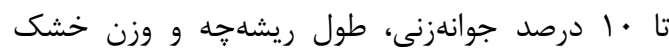
ساقهجه و كياهجه ارقام بومى نسبت به ارقام اصلاحشده

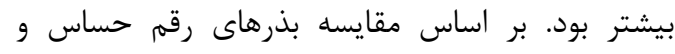
متحمل حاصل از شرايط بدون تنش شاخص، سرعت و و

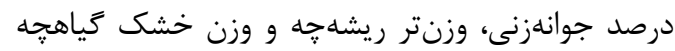
رقم حساس نسبت به ارقام متحمل بيشتر بود. از سوى رئ

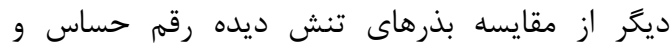

\section{منابع}

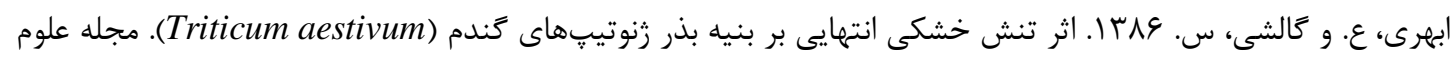




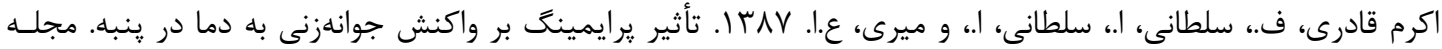

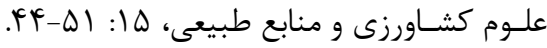

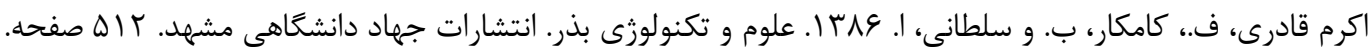

$$
\begin{aligned}
& \text { جاويد، ح. اصفهانى، م. و صبورى، ص. • وبا ا. اثر سه روش خرمن كوبى بر تركخوردگى دانه، جوانهزنى بذر و رشد گياهجه }
\end{aligned}
$$

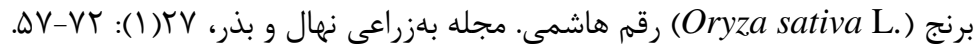

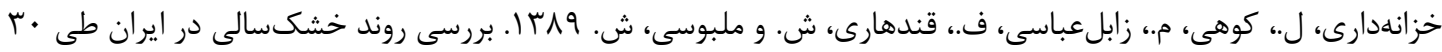

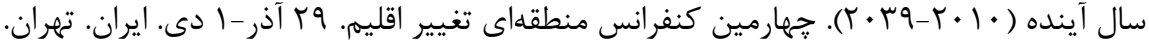

$$
\begin{aligned}
& \text { خليلىاقدم، ن.، سلطانى، ا.، لطيفى، ن. و قادرىفر، ف. اوجا. تأثير شرايط محيطى بر بنيه بذر سوياى نواحى مختلف ايران. }
\end{aligned}
$$

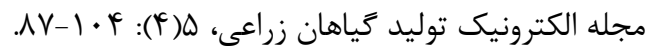

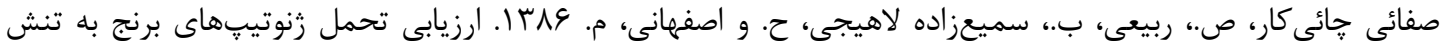

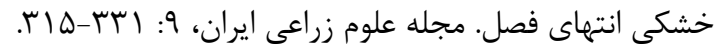

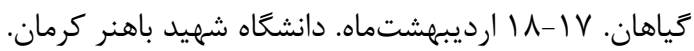

Abdoli, M., and Saeidi, M. 2012. Effects of water deficiency stress during seed growth on yield and its components, germination and seedling growth parameters of some wheat cultivars. International Journal of Agriculture and Crop Sciences, 4(15): 1110-1118.

Abdul-Baki, A., and Anderson, J.D. 1973. Vigor determination in soybean seed by multiple criteria. Crop Science, 13: 630-633. https://doi.org/10.2135/cropsci1973.0011183X001300060013x

Agarwal, R.L. 2003. Seed technology. Publication Company Limited New Delhi, India. 550p.

Alqudah, A.M., Samarah, N.H., and Mullen, R.E. 2011. Drought stress effect on crop pollination, seed set, yield and quality. In Alternative farming systems, biotechnology, drought stress and ecological fertilisation. Springer Netherlands. 193-213. https://doi.org/10.1007/978-94-007$\underline{0186-1 \_6}$

Anonymous. 2014. Standard Evaluation System for Rice (SES). IRRI (International Rice Research Institute) Loss Banos, Leguna, Philippines.

Aruna, M.J. 2013. Effect of withholding irrigation water after complete heading on rice yield and seed quality in Mwea, Kirinyaga county-Kenya. Ph.D. Dissertation Department of Agricultural Science and Technology, Kenyatta University, NAIROBI.

Balkan, A. 2012. Effect of artificial drought stress on seed quality of bread wheat. Iranian Journal of Plant Physiology, 2(2): 403-412.

Crusciol, C.A.C., Toledo, M.Z., Arf, O., and Cavariani, C. 2012. Water supplied by sprinkler irrigation system for upland rice seed production. Bioscience Journal, 28(1): 34-42.

Diaz, C., Hossein, M., Merca, S., and Mew, T. 1998. Seed quality and effect on rice yield: finding from farmer participatory experiments in central Luzon, Philippine. Journal of Crop Science, 23(2): 111-119.

Dornbos, D.L., Mullen R.E., and Shibles, R.E. 1989. Drought stress effects during seed fill on soybean seed germination and vigor. Crop Science, 29(2): 476-480. https://doi.org/10.2135/cropsci1989.0011183X002900020047x 
Dornbos, D.L., and Mullen, R.E. 1985. Soybean seed quality and drought stress intensity during development. Iowa Seed Science, 7: 9-11.

Farooq, M., Wahid, A., Kobayashi, N., Fujita, D., and Basra, S.M.A. 2008. Plant drought stress effects, mechanisms and management. Agronomy for Sustainable Development, 29: 185-212. https://doi.org/10.1051/agro:2008021

Ghassemi-Golezani, K., Lotfi, R., and Norouzi, M. 2012. Seed quality of soybean cultivars affected by pod position and water stress at reproductive stages. International Journal of Plant, Animal and Environmental Sciences, 3: 119-125.

Ilieva, V., Mitrev, S., Karov, I., Markova, N., and Todorovska, E. 2013. Seed quality and its importance in agricultural production and safety of agricultural products. In: International Conference "Quality and Competence 2013", 13-15 June 2013, Ohrid, Macedonia.

ISTA. 2004. International rules for seed testing. The International Seed Testing Association (ISTA), Zurich, Switzerland.

Maguire, J.D. 1962. Speed of germination-aid in selection and evaluation for seedling emergence and vigour. Crop Science, 2: 176-177. https://doi.org/10.2135/cropsci1962.0011183X000200020033x

Mushtaq, R., Katiyar, S., and Bennett, J. 2008. Proteomic analysis of drought stress-responsive proteins in rice endosperm affecting grain quality. Journal of Crop Science and Biotechnology, 11(4): 227-232.

Nam, K.H., and Kim, C.G. 2015. Effects of water stress on chemical composition of rice grains. CNU Journal of Agricultural Science, 42(1):1-5. https://doi.org/10.7744/cnujas.2015.42.1.001

Nam, K.H., Kim, D.Y., Shin, H.J., Nam, K.J., An, J.H., Pack, I.S., Park, J.H., Jeong, S.C., Kim, H.B., and Kim, C.G. 2014. Drought stress-induced compositional changes in tolerant transgenic rice and its wild type. Food Chemistry, 153: 145-150.

https://doi.org/10.1016/j.foodchem.2013.12.051

Samarah, N., and Alqudah, A. 2011. Effects of late-terminal drought stress on seed germination and vigor of barley (Hordeum vulgare L.). Archives of Agronomy and Soil Science, 57(1): 2732. https://doi.org/10.1080/03650340903191663

Shahi, C., Kiran Bargali, V., and Bargali, S.S. 2015. How seed size and water stress effect the seed germination and seedling growth in wheat varieties? Current Agriculture Research Journal, 3(1): 60-68. https://doi.org/10.12944/CARJ.3.1.08

Smiciklas, K.D., Mullen, R.E., Carlson, R.E., and Knapp, A.D. 1992. Soybean seed quality response to drought stress and pod position. Agronomy Journal, 84: 166-170 https://doi.org/10.2134/agronj1992.00021962008400020008x

Vieira, R.D., Tekrony, D.M., and Egli, D.B. 1992. Effect of drought and defoliation stress in the field of soybean seed germination and vigor. Crop Science, 32: 471-475. https://doi.org/10.2135/cropsci1992.0011183X003200020037x

Yan, D., Duermeyer, L., Leoveanu, C., and Nambara, E. 2014. The functions of the endosperm during seed germination. Plant and Cell Physiology, 55(9): 1521-1533. https://doi.org/10.1093/pcp/pcu089

Zibaee, A. 2013. Rice: importance and future. Journal of Rice Research, 1(2): e102.

Zubaer, M.A., Chowdhury, A.K.M.M.B., Islam, M.Z., Ahmed, T., and Hasan, M.A. 2007. Effects of water stress on growth and yield attributes of Aman rice genotypes. International Journal of Sustainable Crop Production, 2: 25-30. 


\title{
Effect of Drought Stress at Reproductive Stage on Seed Germination Characteristics of Local and Improved Rice (Oryza sativa) Genotypes
}

\author{
Seyedeh Arhameh Fallah-Shamsi ${ }^{1}$, Hemmatollah Pirdashti ${ }^{2,}$, Aliakbar Ebadi ${ }^{3}$, Masoud \\ Esfahani $^{4}$, Mahmood Raeini ${ }^{5}$ \\ ${ }^{1}$ Ph.D. Student of Agronomy, Sari Agricultural Sciences and Natural Resources University, Sari, \\ Iran \\ ${ }^{2}$ Associate Professor, Department of Agronomy, Genetics and Agricultural Biotechnology Institute \\ of Tabarestan, Sari Agricultural Sciences and Natural Resources University, Sari, Iran \\ ${ }^{3}$ Assistant Professor at Rice Research Institute of Iran, Agricultural Research Education and \\ Extension Organization (AREEO), Rasht, Iran \\ ${ }^{4}$ Professor, Faculty of Agricultural Sciences, University of Guilan, Guilan, Iran \\ ${ }^{5}$ Professor, Department of Irrigation, Sari Agricultural Sciences and Natural Resources \\ University, Sari, Iran \\ "Corresponding author, E-mail address: h.pirdashti@sanru.ac.ir
}

(Received: 19.09.2016 ; Accepted: 11.03.2017)

\begin{abstract}
In order to study drought stress effect at the reproductive stage on seed germination characteristics of seven rice genotypes, an experiment was carried out at Sari Agricultural Sciences and Natural Resources University in 2014. This study was conducted on drought-stressed seeds and seeds grown under normal conditions. The results of orthogonal mean comparison among nonstressed seeds showed that local genotypes had a lower germination index, germination rate, water percentage of seedling tissue, shoot length and root dry weight than the improved genotypes. Among stressed seeds, however, local genotypes had a higher germination index and germination rates than those of improved genotypes. Comparison of non-stressed seeds of susceptible and tolerant genotypes indicated that susceptible genotypes had a higher germination index, germination rate and germination percentage than tolerant genotypes. On the other hand, the comparison of the stressed seeds of susceptible and tolerant genotypes revealed that drought stress increased the time to $10,50,90$ and $95 \%$ germination, water percentage of seedling tissue and plantlet length in susceptible genotypes, which were higher than those of tolerant genotypes. In conclusion, it seems that drought stress at reproductive stage has a significant effect on germination characteristics of the plant's following generation. However, their responses are different, depending on the level tolerance of the genotype to stress and genetic origin.
\end{abstract}

\section{Keywords: Allometric coefficient, Drought stressed seeds, Germin, Vigor index}

\section{Highlights:}

1- Drought stress at reproductive stage has a significant effect on germination characteristics of the following generation of the rice plant.

2- Among stressed seeds, local genotypes have a higher germination index and germination rates than those of the improved genotypes.

3- Drought stress increases the time of germination in susceptible genotypes, which is higher than that in the tolerant genotypes. 